\title{
A Study on the Art of Qi Opera of Hakka Homeland Ninghua*
}

\author{
Tao Zhang \\ Overseas Education College \\ Xiamen University \\ Xiamen, China 361102
}

\begin{abstract}
Qi Opera is originally the local opera in Hunan, with long history, rich heritage and wide popularity. After the introduction to Hakka homeland Ninghua, Qi Opera preserves the ancient charm completely, which is compared to the "living fossil" of the ancient Qi Opera by the opera experts, and makes Qi Opera really become the Ninghua Qi Opera with distinct ancient color, which is the precious Hakka intangible cultural heritage. This article traces the origin and expansion of Qi Opera, its introduction to Ninghua and the history of its popularity in Ninghua, explores and analyzes the artistic features of Ninghua Qi Opera, demonstrates the heritage significance of Ninghua Qi Opera, and forecasts its future development trend.
\end{abstract}

Keywords-Hakka; Ninghua; art of Qi Opera

\section{INTRODUCTION}

Qi Opera is originally the local opera in Hunan, with long history, rich heritage and wide popularity. After the introduction to Ninghua, it becomes a wonderful work of folk opera. Its performance patterns of singing, chanting, acting, and playing completely retain the ancient charm of Qi Opera, which is compared to the "living fossil" of the ancient Qi Opera by the opera experts, and makes Qi Opera really become Ninghua Qilian opera with distinct ancient color. It is declared by Ninghua County of Fujian Province and listed in the list of the first municipal intangible cultural heritage in Sanming City. At the same time, it will declare the project of intangible cultural heritage of Fujian Province.

\section{THE INTRODUCTION OF QI OPERA}

\section{A. The Origin of Qi Opera}

Qi Opera is originated in Yiyang tune. According to legend, during Yongle period (1403-1424) of the early Ming Dynasty (more than 500 years ago), Jiangxi Yiyang tune was spread to Qiyang city, Hunan province along with the local immigrants, and then it is fused with the folk art of Qiyang city. After a long period of evolution, Qi Opera was finally formed. At that time, it was known as "Qiyang Opera", also known as "southern Chu Opera". Ninghua people called it "Hunan Opera", which is all because of its formation in

*This paper is a phased achievement of the Fujian Provincial Social Science Planning Project "Research on Ninghua Hakka Art as a Nonmaterial Cultural Heritage" (2008B116)
Hunan Qiyang. According to verification, "Story of Mulian" is originally the traditional theatrical pieces of Yiyang opera and later is known as the ancestor of Qiyang Opera Gaoqiang. There are "story of ancient city", "story of conquering Liao", "story of shooting deer", "story of carp", "story of digging eyes", "story of stealing peaches", "story of clay pot", "story of brocade", and "Butterfly Dream" and other repertoires of Yiyang opera are also retained. The origin of the relationship can be seen.

Since ancient times, string song is popular in Qiyang County in Hunan Province, and the proverb "on one can win Qiyang in singing" is spread in the folk, so it has a solid social foundation for the absorption, integration and innovation of singing art. Gao Qiang, originated from Yiyang Opera, is the earliest tune of Qi Opera. During the Wanli period of the Ming Dynasty, Qi Opera embraced the popular Kunshan opera, thus enriching its own tune and adding many repertoires. Until the late Kangxi period of Qing Dynasty, Qi Opera continuously integrates Anhui opera, Han opera and Western qian opera and gradually forms the Tanqiang (North-South Road). The tune is further enriched and Qi Opera rapidly becomes mature. The number of famous artists is increasing and the range of their popularity is expanding. In order to meet the needs of different audiences in different regions, the artists try to sing their own styles in tune, and then two major schools of Yonghe School and Baohe School have come into being. Yonghe School mainly plays the Tanqiang opera and is assisted by drummers. Baohe School plays Gaoqiang opera more and is accompanied by suona. The stage language is Qiyang mandarin. There are many operas, with rich Qupai, sonorous and rugged vocal music. It is a kind of local large-scale opera in Hunan with multiple tunes dominating by Tanqiang. It has a strong mountain atmosphere.

According to the Qiyang County Records of Yi Wen Records compiled in the 9th year of Tongzhi in the Qing Dynasty, activities of theatrical troupes in the late Ming are frequent, and the system is relatively sound. Qi Opera is increasingly popular in Hunan, especially in southern Hunan. In the period of Kangxi and Qianlong of Qing Dynasty, the troupe became more active, developed rapidly, spread widely, and had an extensive influence. It had a good audience base in many areas such as Hengyang, Shaoyang, Lingling, Binzhou, Qianyang and so on. Many literati were proud of 
being able to sing a few lines of opera text. After Xianfeng and Tongzhi period, Qi Opera developed in an all-round way, and opera school of Qi Opera emerged everywhere, like bamboo shoots after a spring rain. With the increasing of new opera club and new repertoire being performed frequently, famous schools and famous actors gradually emerge, and auspicious class and old four-joy class has been famous in Jiaqing period. According to the information, from Xianfeng and Tongzhi to the eve of the War of Resistance Against Japan, Qiyang County had 42 opera schools, such as Hong, Yuan, Ru, Yong, Xiang, Fang, Xiang, Mei, Yu, Chui, Wen, San, Xi, Rong, Guo, Li, Qiao, Chun, Chao and so on. Among them, Li Yuliang of the Yu School, Tang Sanxiong of the $\mathrm{Cu}$ school and Liu Xigen of the $\mathrm{Xi}$ school are called three half-intelligent children of Qi Opera. They are all artists of great importance for a time. The school that cultivates the most talents should be "Rong" opera school. For example, the famous chou Li Rongfu, famous sheng $\mathrm{Li}$ Rongzhen, and famous dan Su Ronglan have been wellknown in Hunan-Guangxi district, and enjoyed a high reputation in Qi Opera. The Lihua School founded in Hongqiao, Qiyang, in the Republic of China was the first women's opera school of Qi Opera, which made a new breakthrough in training specialized talents for subsequent undertakings of Qi Opera.

\section{B. The Expansion of Qi Opera}

The spread and expansion of Qilian opera first returned to Jiangxi. There is the saying "three to south of Jiangxi Province" spreading among artistes, which in fact means that opera expand outward through the channel of southern Jiangxi. By and large, the first batch outspread in the Qianlong period of the Qing Dynasty. At that time, Yuepu School, Tianqing School, and Wenhua School and so on had performed far to the Guangdong Provincial. The second batch was guided by the "Renhe School" in late years of Tongzhi period. The third batch was represented by the "Fuxing School" in the late Qing Dynasty and the early Republic of China. The outspread of each batch has further expanded the disseminating area, and successively extended to the vast areas of Jiangxi, Fujian, Guangdong, and Guangxi and so on.

Of course, an opera spreading to one place to take root and blossom cannot be achieved by one or two performances of a troupe. The introduction of the Qi Opera to Ninghua is closely related to the profound influence of the Qi Opera in the whole western Fujian area. The troupe can only focus on one place and then perform in the surrounding places when coming to the western Fujian. After a long time, the impact is deep, and Ninghua is no exception. In the Qianlong period of the Qing Dynasty, when the first batch of Qi Opera artists who go to southern Jiangxi for three times are outspreading, Qi Opera troupe has already entered the western Fujian area, and it is natural for them to enter the western Fujian from the southern Jiangxi. The Hakka ancestors crossed the Wuyi Mountain from the southern Jiangxi to the western Fujian. According to the old artist Xie Guixi, "...the earliest natives who learn the opera in Luofang (Liancheng County), Luo Changyin, were born in the year of Emperor Qianlong wushen of the Qing Dynasty and famous for painted role. Two of his masters from Hunan died in Luofang. The children and grandchildren of Luo Changyin, as instructed by their ancestors, will sweep the tombs of these two artists who died in a strange land each year in the spring and autumn." These words reveal us some other information: First, Qi Opera has visited the counties of western Fujian frequently in the Qianlong period, and win villager's love from stage to offstage. Luofang is just an epitome. Second, Qi Opera triggered the desire of local people to learn art, and there are also many Qi Opera artists spread the art out, so Qi Opera can be spread quickly. Third, the number of troupes performing in Ninghua should be no less than that in the adjacent counties such as Liancheng. Qi Opera also sows seeds in Ninghua and only waits for suitable temperature for germination. In fact, in the early years of Tongzhi, "Chunfu troupe", "Shuanggui troupe", "Futai troupe" and "Rongde troupe" of southern Chu have performed in Luofang. In just a few years there have been many troupes performing in one township, and it is obvious that the performance activities in other county cannot be inactive. This may be the second batch and the third batch of outspread of the "going to southern Jiangxi for three times". It is pointed out in The History of Chinese Opera in Fujian that Qi Opera may be spread into western Fujian from southern Jiangxi since Fujian and Jiangxi are neighbors, and soon become popular in Ninghua, Qingliu, Guihua (now Mingxi), Jianning, Yong'an, Liancheng, Longyan and Shanghang." 1 This not only continues to draw the spread route of Qi Opera in southern Jiangxi for us, but also implies the extensive impact of Qi Opera in the West Fujian for us. Ouyang Yuqian, a famous dramatist, also said in the 1930s that "The script of the Western Han Dynasty in Fujian was derived from the Qiyang opera." The Qilian opera was originally the ancestor of the Han opera in western Fujian. The local opera, inheriting Jiangxi Yiyang tune and passing to the West Fujian Han opera, shows its powerful vitality. Southern Jiangxi and western Fujian belong to Hakka, Qi Opera is particularly popular among Hakkas.

In a word, Ninghua, the land in which the flower of Qi Opera can be bloomed and propagated, is gradually fertile through the cultivation and irrigation of several generations of artists.

\section{Visit of Qi Opera Class of "New Spring Hall"}

Since the establishment, there is no local opera in Ninghua County. There is no textual research on the literature of the year when the opera began to be staged in China. In the traditional view of the old society, artists are regarded as "actors" that "are princes when they are on stage and beggars off the stage" since their social status is low. In addition, Hakka people lead a poor life and are poor in cultural life. The market for performances by troupes from other places is narrow, with only a few people coming, making it difficult to make an impact. Therefore, there are few records in the local chronicles and the family tree.

Editorial Committee of Chinese Traditional Opera Records, Fujian Volume of Chinese Traditional Opera Records, Culture and Arts Publishing House, 1993. 
According to the survey, the earlier type of opera that was introduced is the Hunan Qi Opera, which arrived in Fangtian during the Qianlong period of the Qing Dynasty. As recorded in records of culture of Ninghua County, on the wood wall of the back-stage dressing room of the ancient stage of the Ancestral Temple of Dashe Village in Fangtian Township, it is found that there is a performance mark written with a brush by the opera troupe at that time: "Hunan 'Xin Xi Tang' came to perform here. Good luck to Open up. Cold Food Festival in Bingchen year of Emperor Qianlong." According to textual research, the "Xinxitang" is Qi Opera Troupe, and the year Bingchen Qianlong is 1736. Therefore, Qi Opera has been introduced into Ninghua for more than 270 years. Because the performance art of Qi Opera is exquisite, the repertoire is easy to understand, the discourse is relatively close, and the later "new Fu Xiang" troupe also settles ouside the city gate to establish school to teach opera, making Qi Opera take root soon in Ninghua and be deeply loved by the common people. Later, Jiangxi tea-picking opera, which was popular in the 1830 s, is then introduced. It get popular among the broad masses because its content is close to life, the story has strong human feelings and the language is vivid and simple. In the early days of the War of Resistance Against Japan, Peking Opera of southern Fujian performed in Ninghue, and it also made a big hit. Besides, Guangdong Cantonese opera and Western Fujian Han opera have also come here for performance, but did not cause a great effect. After the founding of the People's Republic of China, Zhejiang Yueju was introduced by the government. Because the language gap is far, and it is not easy to learn although good looking, it has not been popular in the private community. It is said that Nuo opera and Nuo dance Ninghua are also popular in Ninghua. It is an ancient culture of $\mathrm{Wu}$ Nuo, featuring "exorcism" by wearing a mask to dress up as gods. On the old festivals, it is often performed in in the ancestral halls, of which the action is clumsy, primitive and simple. Now the "You Nuo" remaining in Xia Fang has evolved into a kind of entertainment during the local "rippling period" (lively folk festivals with many people). Throughout the performance activities of various operas in Ninghua, Qi Opera is first introduced, and later remained for the longest time, with the most extensive influence on the masses and the deepest roots at the grassroots level. A study of Qi Opera was launched in both urban and rural areas. From Qi Opera "Qu Peng" (a simplified form of opera that only performed by singing and changting without getting on stage, making up, acting, or playing) to the amateur opera club of Qi Opera, performance of Qi Opera can be seen almost everywhere. It should be said to be the most audience-based opera. After the changes of history, experts hold that the Hunan Qi Opera has already been improved and changed, but Ninghua Qi Opera retains the ancient charm of original Qi Opera, and its performance patterns of singing, reciting, acting, and playing and so on are "the living fossil" of Hunan ancient Qi Opera Therefore, the present Ninghua Qi Opera takes the lead because of its distinct ancient charm of Qi Opera. In this sense, the original Hunan Qi Opera has been transformed into real Ninghua Qi Opera.

\section{THE POPULARIZATION OF QI OPERA IN NINGHUA}

\section{A. "New Fuxiang" Establish School to Teach Opera}

According to the memory of Qi Opera artists Wu Zhongchun and Zhou Zhongmei in Ninghua, in the second year of Xuantong at the end of the Qing Dynasty (1910), Qi Opera artists Long Mingxin led the "New Fuxiang" troupe from Qiyang to perform in Ninghua and other places in western Fujian. The performing activities of the troupe lasted more than 40 years in Ninghua. They successively founded three opera schools in Ninghua, namely Xiang, Zhong and Yong, and they were the apprentices in the second school. (Note: No wonder the names of the two people contain the character "zhong", it should be the stage name) therefore, Qi Opera really took its root in Ninghua. It should be said that "New Fuxiang" has contributed a lot for the fact that Qilian opera can take root in the Hakka area thousands of miles away.

The school owner Long of the "new Fuxiang" is an old artist who is proficient in sheng, dan, chou, and jing, with deep attainments of opera. When the troupe arrives in Ninghua, it takes the city gate as its foothold to go on a tour in the townships in the county, or take turns performing in the neighboring counties such as Jianning, Qingliu, Mingxi, Liancheng, Yongan, Datian, and Longyan, etc. Wherever they go, they are welcomed. A few years later, when the troupe owner Long saw the enthusiasm of the masses for Qi Opera, he decided to set up the class in Ninghua to widely recruit apprentices and pass on technical skills. Before and after he organized three opera schools and cultivated a number of excellent students of performing arts. Some of them expand their team, some of them become the backbone of local "Qupeng" or "opera club". In addition, the troupe owner Long betrothed his daughter who plays the leading role in the troupe, to his excellent student Lei Bilu and handed over the power of the troupe to them. This has given the troupe more vitality, the number of performances has increased, and the opera has attracted more people. The troupe has exerted a profound influence among the masses, and it has become popular for a time. Qi Opera hot quietly rise, and villages in Ninghua have spontaneously organized "Qu Peng" to learn the singing skills of Qi Opera. In the areas of Hekou and Huaitu in Chengguan and Xixiang, mass entertainment groups such as "Jinsheng club" and "Tongfu club" were set up. Because they shared a common hobby, they passed down Qi Opera from generation to generation and spread widely in the urban and rural areas of this county. Later, some developed into amateur "opera clubs" to raise money to buy outfits and props to perform on stage. Professional Qi Opera class have also been established in Chengguan, Shuixi, Helong, Hekou, Jicun and other places to perform in the county and nearby counties and township.

In the first month of 1929, the Cantonese opera troupe "Saitaoyuan" also came to Ninghua, where they happened to meet the City God Temple Fair. They immediately decided to set up another stage on the right side of the City God Temple to perform at the same time as Qi Opera "New Fuxiang" class, which was performing at the Temple. As a result, the audience was feasted on and both sides were 
praised. However, after that, "Saitaoyuan" troupe still do not want to stay, and then leave Ninghua for other places. Everyone understands that the performance of the two troupes together is not only a watching competition, but also a competition in the market. The troupe "Saitaoyuan" withdrew from Ninghua after knowing the difficulties, which shows the advantage of Qi Opera in Ninghua.

\section{B. The Rise of "Qu Peng"}

According to statistics, Ninghua had a total of 26 "Qu Peng", and up to 36 amateur Qi Opera troupe at that year. What is particularly amazing is that almost every village has an opera stage, and even a small village with only a dozen families is no exception. The stages are generally built in ancestral halls, temples or public places, with wooden frame structure and different sizes. Some are quite exquisite, often with dragon and phoenix or Kirin painted on the stage ceiling and dressing room behind the stage. All of these are the witness of the prosperity of rural opera activities. The prosperity of opera activities greatly enriched the cultural life of the masses, improve the cultural literacy of the masses, and promote the prevailing custom of unity, friendship, and harmony.

"Qu Peng" is a folk art organization, commonly known as "singing opera". That is, several "singing" people are sitting around two or three long tables made up of square tables. They unfold their Qupai books, set up gongs and drums, and sing opera arias impromptu according to the play the sequence of roles in the repertoire, with spoken parts inserted and instrumental accompaniment. It proceeds in proper order until the end of the play. Before singing, there is a section called "Dachaotai", which refers the band beats the gong and the drum to make the stage and play Guomen and Tuoqiang. In general, they have to hit three times, with the first two times only beating, and then start singing after the third beat, to create a theater-like atmosphere from beginning to end. The repertoire can be divided into different sizes. The major programs are "Tian Gong", "Tian Shui Guan", "Jin Gong" and "Ma Dian". The minor programs mainly use the popular lyric songs or qupai, dominating by southern tune of Qi Opera such as "Guaziren", "Ten cups of wine", "White Peony" and "play dominoes". The ability of "singing" and "chanting" and instrumental accompaniment are the same as the performance on stage, but they do not make up and go on stage and there isn't the scene of "acting" and "playing" . Some say this is the embryonic stage of the troupe, while others say it is a simplified form of opera. Because its equipment is simple and the site is easy to find, it is very suitable for rural economic and cultural conditions. On every festival and during the fallow period in winter and spring, they often hold activities on appointed day to entertain themselves. When there is the invitation from wedding and birthday celebration, they also come to the scene to sing for fun to entertain guests and create festive scene. This art form active in folk plays a very good role in promoting the popularization and spread of Qi Opera in rural areas.

\section{Development of Amateur Troupes}

In the 1950s, there were as many as 41 active amateur Qi Opera troupes in the towns and villages of Ninghua. In Helong Township alone, there are four troupes including Helong, Xia Yi, Mingzhu, and QianJin. There are more than 30 actors in each troupe. At that time, they collect money to buy props, clothing, and musical instruments to set up Qi Opera Class depending on each villager donating a load of millet (or 50 yuan). They also invited the master of Hunan Qi Opera with more than a dozen apprentices to be the backbone of the troupe. At that time, everyone's enthusiasm was very high. During the day, they worked in the fields. At night, they studied the opera with the light of turpentine until late into the night, and none of them complained about it. These Qi Opera troupes mainly performed in the villages of the surrounding counties of this county, Jianning, and Shicheng, Jiangxi. Most of them perform traditional operas such as "Pearl Pagoda," "Erdumei" "The Story of Treasure," and "Jinbaozhu." They are popular in the villages lacking in cultural life, and can perform for more than 40 days (80-odd) a year. In some villages, they have performed for seven consecutive days. In the 1950 s to 1960 s, during the traditional festivals of the Lantern Festival and Mid-Autumn Festival, the county departments often organized Qi Opera performances, which promoted the exchange and development of Qi Opera.

\section{Wide Mass Base}

In Ninghua, there is also the story of an old Qi Opera fans: in Xiawu village of Chengjiao, Qi Opera troupe are invited to play every spring and autumn. There is an old blind fan called "Jinbaolao", who will come to watch the play from Lishe village two or three miles away whenever there is a play regardless of the weather. He can hum a few paragraphs when he hears a lot. Once, when the troupe performed "Muke Zhai", and the actors who played Jiaozan came on stage, he made up the lines: "The Wufang is made up as satge, and a gourd shed was built in front of the ancestral temple; big gourds are digged to be spoon, and small ones are picked to cook soup." He wanted to vent his dissatisfaction with the poor food, but as soon as the show was over, Jinbaolao immediately protested to the troupe and asked the class owner to apologize. A blind old man could hear the adulteration of lines in the performance, showing that he already knew all too well the words and phrases of the opera that is often palyed. This extensive mass base makes Qi Opera out of the limelight on the stage in Ninghua.

Qi Opera is an opera from other places. Why can it be so beautiful in Hakka settlement of Ninghua and inherited up to now? Among the various operas performed directly in Laining, why is Qi Opera preferred only? These questions did trigger many people's interests. The author believes that there are five specific reasons for this except for the strong inclusiveness of Hakka culture: First, the art of Qi Opera is magnificent with exquisite performance, bright outfits, and solid skills. The actors are good at both writing and playing and the mountain atmosphere is very strong, which can attract the audience. In addition, the dress of Qi Opera has distinctive features. In particular, the boa and armour are 
made of guangxiu and embedded with a large number of small mercury round lenses, which is particularly dazzling in the light, adding to the actors' performance and making people pleasant to enjoy. Second, Qi Opera has wide opera routes with many historical plays. Among the nearly 100 operas circulated in Ninghua, most of them are folk stories about praising virtue and punishing vice and retribution for sin, such as "Killing the Child", "Buddhist nun go Down the Hill", "Water Flooding Jinshan Temple", "Old Mother Guanyin Traveling to the nether world", and "palm-leaf fan" and so on. The plots of these traditional dramas have long been widely read in the locality, and are well known to people, so they appear on stage like old friends. Third, Qi Opera is rich and colorful in vocal music, the lyrics are easy to understand, the melody of music is clear and pleasant, the musical instrument is warm and high, and the opera is touching, elegant, popular, and beautiful, which is suitable for the appreciating habits of many people. Many people can sing freely, and become the loyal fans. Fourth, Qi Opera used Qiyang local mandarin as the spoken parts, which belongs to Hakka language with Ninghua local mandarin and is relatively close. In the countryside with underdeveloped culture, most people can understand. Only by being "understood", can the art play its charm and become the spiritual enjoyment of the audience. Fifth, Qi Opera "Xinfuxiang" class stayed in Ninghua for a long time, and advocated to do as the Romans, so the relationship with mass is relatively close, which strengthened people's interest in opera. Once, during a performance in Hengsuo Township, the class owner, Long Mingxin, learned that the people in the nearby village of Longxia Ke were also named Long, and that there was a temple of the Long family. He immediately rushed to the temple to pay respects to the ancestors, and held a ceremonious sacrificial ceremony, which won the respect and praise of the local relatives. For a time, it became a good story and was widely heard in the county town, so that the audience generated good feeling and accepted the troupe from their feelings.

In addition, there are two points worth mentioning. First, Qi Opera performance is permeated with rugged mountain atmosphere, which can be regarded as the reproduction of "wild culture". The so-called "wild culture" is the first civilian culture and original culture of mankind, which is the instinct that is still retained. The famous scholar Lin He thinks: "The cultural gene of the Chinese civilization exists in the wild culture" 2 . Naturally, "the wild culture" gene also affects the Chinese civilization in turn. The wild performance of Qi Opera makes the common people's instinct psychology be full satisfied, or is said to be "the pleasure". Just like the children like "the animation", everybody likes to watch the opera. Second, Qi Opera is introduced earliest, and the masses contact more, so it forms the advantage of "entering first" in thought. In addition, "Xinfuxiang" class officially recruits students to pass on skills and speed up the spread of Qi Opera, creating Gene of Chinese Civilization, Guangdong flower town Publishing House, 2001. favorable conditions for Qi Opera to take roots in Ninghua, so that it eventually becomes a part of the local culture.

\section{The ARtistic FeAtures of NinghUA QI OPERA}

Qi Opera is an ancient and lively local opera. It has been about five or six hundred years since Yiyang Opera was introduced into Qiyang in Yongle period of the Ming Dynasty. In the long process of popularity and evolution, it not only combines the folk minor tune and singing skills of "never sing better than Qiyang", but also absorbs a large number of sister art essence such as Kunqiang, Huizhou tune, Handiao and Yihuang tune, to develop its own voice, expand the performance of the repertoire, and enrich the performing arts. The root of singing, chanting, acting, and playing is deep. Therefore, this wonderful work of opera art can develop into an art form with wide distribution range, long popular age, and distinct performance features, and is loved by the majority of the audience.

\section{A. Excellent Repertoire and Traditional Subject Matter}

The traditional repertoire of Qi Opera includes Gaoqiang repertoire, Kunqiang repertoire and Tanqiang repertoire. According to statistics of 1982 , there were 272 whole plays and 669 sanzhe, totally 941, in which Tanqiang repertoire accounts for about 80 percent, Goaqiang and Kunqiang account for about 20 percent. The operas performed in Ninghua are all traditional repertoires, including "Yibang Snow", Erdumei", "Three Days of Fragrance", "Four Famous Mountains", "Five Tigers and Pingnan", "Six Stars and Qishan", "Seven Arrows", "Eight Essentials", "Nine Gengtian", and "Full of Happiness" and so on. They are the crystallization of the lifetime of the artists.

The script is the basis of a play. Many of the traditional dramas of local operas come from folk stories, and some even have no scripts. Some of them are taught by teachers orally or physically, so many of them have their own ingenuity, and some of the absurdities are unavoidable. Qi Opera artists constantly sum up experience, mine connotation, abandon the rough ones and retain the essence, eliminate the false and retain the true in the long-term performance practice to constantly absorb and draw lessons from the sister arts and learn widely from others' strong points, so that the play can be gradually improved to become a fine art after severe training and hammering. The themes are mostly from all kinds of historical novels and book story that mostly praise loyal justice and expose the dark kings and treacherous ministers. The most important theme is to publicize patriotism, achieve justice, and punish crimes, which has a far-reaching impact on the people. Secondly, the Baogong Drama and Anyuan drama that praises the honest and upright official also occupies a considerable proportion, expressing the expectation and voice of common people. In addition, the dramas showing faithful love and beautiful myth are also not few, which reflects the spirit yearning and pursuit of the common people.

In Gao opera and Kun operas, Yonghe school calls "Mulian Zhuan", "Jingzhong Zhuan", "Guanyin Opera" and "Journey to the West" as the four major operas, while Baohe 
school uses "Fu Zi Opera" instead of "Journey to the West". The basic plot of the seven books 124 fold of Mulian story comes from Zheng Zhizhen's "Mulian Redemption of Mothers" in Wanli period of Ming dynasty. However, the specific single fold is different, such as the one fold of $\mathrm{Nu}$ Ci'an, which is similar to the Buddhist nun going downhill in Ci Lin Yi Zhi, which was published in Wan Li Yuan Year of Ming dynasty. There are eight folds different from Zheng Ben and there are two other unofficial biographies that are not in Zheng Ben. When singing, the seven books are all Goaqiang. "Jingzhong Biography" is also divided into seven books, with three Gaoqiang and three Kunqiang, and the seventh is the co-performance of Gaoqiang and Kunqiang. "Journey to the West" is divided into three books, also with a play of Gaoqiang and Kunqiang, and the third book is coperformance. "Guanyin Opera" is divided into three while "Fu Zi Opera" has 10 in total, which are all Gaoqiang repertoire. Other Gaoqiang operas, such as The Story of the Pipa, The Story of the Jingchai, The Story of the White Rabbit, and The Moon Pavilion, only retain a few scattering folds. The Kunqiang operas such as The Blessing of the Heavenly Officials, The Eight Immortals' Celebrating Birthday, The Imperial Enfeoffment, The Persuading Agriculture and Appreciating Flowers, and The Six States' Enfeoffment are all retained relatively complete. It should be said that these evolution process are those screened in the performance practice and continuously improved.

Bullet chamber is also known as the north-south road, which is a new tune formed by Qi Opera in the early Qing Dynasty through the integration of Huizhou tune, Handiao and Xihuangqiang, so Tanqiang dominates in the middle of the Qing Dynasty and the subject matters are also mainly from a variety of historical novels. For example, "Huang Feihu Fanguan" is from "the Investiture of the Gods"; "eight Yi picture" and "Jing Ke Stab Qin emperor" are from Records of the Gentiles of the Eastern Zhou Dynasty; "Catch and release Cao", "Sacrifice Fengtai", and "Lost space chopped" are from "Romance of the Three Kingdoms". Other works, such as The Romance of the Western Han Dynasty, The Romance of the Eastern Han Dynasty, The Story of the Tang Dynasty, Expedition to the east, General Father General Son, Destined To Rebel, generals of the Yang family, The Complete Story of Yue Fei, and Water Margin etc, have been adapted into Tanqiang dramas. Some of them have been transplanted from brother dramas and popular among the masses.

\section{B. Excellent Performance and Superb Skill}

1) Performance: The type of roles in Qi Opera is the same to its sister art, including four types of sheng (Zheng Sheng and Xiao Sheng), Dan (Zheng Dan and Xiao Dan), jing (first hua and second hua) and chou (Wen Chou and Wu Chou), and Lao Dan is classified into the type of Zheng Dan. Each type of role has two to four people, and each role plays both singing play and military play. Each of them has their own characteristics. For example, Zheng Sheng opens a play; the old dan answers "spoken parts" and the two hua also play colorful Dan. They must be proficient in singing, chanting, acting, and playing, and the performing procedures are very standardized. For example, "appearance", must be placed after pulling sleeve, shaking sleeve, neatening crown or tidying temples; "cardigan" includes two types of whole cardigan and half cardigan, which can't be mixed; the set of procedures that shows the general, nobility and military generals prepare for the war requires difficult movements and rigorous specifications, which is unique to Qi Opera.

The performance art of Qi Opera comes more from life, and then is processed into art and dance. It is characterized by simple and frank and perform happiness, anger, sadness and joy with great eloquence. Crying should be like a true cry, and smile should be like true smile. It is rough, hearty and rich in mountain atmosphere. For example, in "fighting Machao at night", Zhang Fei has a desperate struggle without any disguise; in "Ma Gang hit the gate", Ma Gang hit the gate with mace, showing his wild nature; Qin Can in "Qin Fu Diming" attacks table and throw the table, with the soulstirring artistic effect. Even love operas such as "farewell in Congtai" also mixes rough with detail. When forced to marry to others, Chen Xingyuan have to bid farewell to her fiance. She bites him on the wrist, and caresses him in his exclamations, which expresses Chen Xingyuan's complex psychology of love and hate. Besides, integrating folk sword and boxing in fighting scenes and transferring the actions like horsing, boating, going up the mountain, and going down the mountain into dance steps not only are very vigorous and beautiful, but also reveal a strong mountain flavor.

2) Art of singing: The art of singing of Qi Opera is highly skilled and has solid foundation. In order to adapt to the vocal music with high tunes, the use of the tunes according to one's own understanding is very ingenious. In addition to the lao dan and chou who use the real voice, the rest roles use "sleet", namely the combination of real and false voice. Concretely speaking, the hua roles sing the high voice, young sheng uses the consonant, and young dan sings the narrow voice. The sheng often uses falsetto, but sometimes sings the original sound. The main feature of Qi Opera is that dan sometimes uses prolongation of tune "yi" to end the sound when it comes to end. The high melody is like falsetto. Furthermore, the use of "Bayin" and "Tiger sound" by hua role is also an important symbol of the art of singing of Qi Opera. "Bangyin" uses falsetto to pronounce, with very high tone, but the high tone is more generous and grand compared to that made by small sheng with falsetto, which can show a brave and strong character and momentum. "Tiger sound" refers to the sound from the nostrils. When pronouncing, "Hum" sound is made in the nostrils, like an angry tiger, which has good artistic effect in the expression of characters' anxious, anger or hatred. Singing requirements are very strict. Clenching word should pay attention to single, double, empty, and solid, and pronouncing stresses cadence, so as to achieve the correct word, clear sound, and full tune. 
3) Skill of acting: Qi Opera especially emphasizes on acting. In the traditional repertoire, there are many plays of acting, with few sing words, and spoken words. It all relies on the performance action to introduce the plot, develop contradictions, and shape the character, so the basic skills of roles are required to be very solid. The body parts of the roles have a set of techniques, and a series of items is listed according to the action form. The hands have "wrist skill", legs have "road skill", and eyes have "eye skill". The rolling of the eyes and the shaking of the facial muscles are the basic skills of the hua role, while the soft "cotton figure" is the skill obtained by dan during the childhood. There are skills in gestures and expressions. "Reaching out hand" require hua role to reach beyond head, xusheng should reach beyond eyebrow, small sheng reach parallel to shoulder, and dan reach parallel to breast. "Wrist skill" is a major feature of Qi Opera, which require the role to practice hands "palm", and play "wrist flower" freely. "Reaching out foot" requires hua role to kick with cross leg, sheng straightly kick with slant leg, and dan kick with the tip of the foot lower than five. "Road skill" is the skill action of horse running. There are scores of kinds including horse running, horse-walking, horse-rushing, horse-receding, horse-throwing, horse-losing, and horse-falling trap and so on. It is often used to highlight the typical environment and the hero image in a variety of connecting suffixes. "Eye skill" is the skill to perform a variety of eye contact. "Cross-eye" is used to perform surprise and anxiety, "staring" is used to express anger or deterrence, "rolling eyes" is used to perform thinking and calculating, and "shaking eyes" is used to perform handsome. There are "opening eyes", "askance eye", "separating eyes", "yin eye", "handsome eyes", "glad eye", which are important means of portraying characters. Its performance action pays attention to the coordination and symmetry of eyes, nose, chest, fingers, and toes, which must meet certain specifications, called "return to the meridian." In addition, there are many special stunts and tricks, such as bianlian, cross, luoxiu work, luomao work, and purple multi-crown work and so on. These graceful body movements form the traditional performance program of Qi Opera with different style.

\section{Resounding Vocal Music and Impassioned Music}

1) Tune: The music of Qi Opera has many tunes including high tune, Kun tune, South Road, North Road, Siping tune, and Anchun tune, known for high pitch and agitation. The number of Qupai is calculated by thousand. According to statistics in 1982, there are 240 high tunes, and 289 Kunqi tune. The number of percussion instruments and qupai is up to 550, accounting for more than half of the total qupai.

The high tune is the most ancient and characteristic tune of Qi Opera. It still retains the characteristics of "the beat depends on drum and the tune is noisy" of Yiyang tune, which means to strike the beat with the drum when singing, and to accompany with gongs, drums and suona to exaggerate the atmosphere. Qupai are divided into four types: south, north, upright, and mix. The difference between south and north is in melody. In the same piece of music, the south song is lyrical and joyful, while the north song is solemn and stirring. The distinction between the upright and mix is that continuous stage sings the upright height, while the other high tunes sing the mixed height, also known as playing high tune. The part of several roll singing sentences has little words and many sounds, with strong reading sense.

Kun Opera is divided into two types: Zhengkun and Shuakun. There are more than 300 pieces Qu Pai retained. The structure of Qu Pai is divided into the principal board and subordinate board. The principal board is four beat with one plate and three eyes, while subordinate board is one plate and one eye and the plate with no eyes. The qupai that perform great emotional excitement and the magnificent momentum is accompanied by suona, and the big gong, big cymbal and big drum are used to strengthen the atmosphere. For narrative lyrical, relaxed and cheerful qupai, flute is used to accompany and a hat-shaped drumming wheel is used.

The tanqiang can be divided into the south road and the north road. The south road is equivalent to "two springs", while the north road is equivalent to "west skin", all of which have the tunes of Siping and Anchun. The melodies of the north and south roads are often used in combination with each other, and are referred to by artists as "turning from south to north, and from north to south." There are so-called "hanging sentences" (also called "missing sentences") and "four-door qiang" in the vocal music, which are unique to Qilian opera. "Crying Hall of Qi emperor" of the south road, "Gaowangjin article" of the north road and "son to be killed" are all repertoires of "hanging sentences". "Four-door qiang" is the special tune for the protagonists to play four roles, such as "Dengzhou at night", "Cong Tai farewell" of the south road and "infuriate Zhou Yu for three times" of the north road. There is the vocal music describing the head turning skin in the silk strings tune of "Man Jiang Hong", which is also unique.

The artistic features of Qi Opera music are mainly manifested in two aspects: tune and mode. On the tune, the melody lines fluctuate greatly, and there are interval jump such as three degrees, six degrees, seven degrees, eight degrees and even nine degrees in some vocal music during the melody. Such as $5 \rtimes 5 \downarrow 3,3 \searrow 5 \rtimes 1 \downarrow 6,5 \searrow 3 \nearrow 5 \downarrow 3$, such melody in the process of large-scale jumps in the interval, making the music style appear very straight, exciting, with very strong ancient rhyme. The changes in mode are also very obvious. In addition to the "5" mode (Huizhou tune) of the south road, the "3" mode (Jiao mode) of the north road has its own characteristics. The main sound " 3 " of the north road is often carried out alternately from the "7" mode to the subordinates "6" mode, which has a different flavor.

2) Musical instruments: The musical instruments of Qi Opera include big gong, small gong, cymbals, small cymbals, Tupan, drums, castanets, flute, Suona, Erhu, Jinghu, Yueqin, tsanxian, and Qin Qin and so on. In order to adapt to the pitch of Qi Opera, the production and 
performance of accompaniment instruments also have their own characteristics. In percussion instruments, Qi Opera uses a special treble drum, hat-shaped noise drum and broad-edged bass gong and cymbals. The combination of this two-high and two-low drums, hitting the beat with drum and accompanying with gongs, drums and suona, can render a different atmosphere of the scene. The use of its gong and cymbals is the most characteristic. Because of its low and rugged timbre, civil and military officers can hit suddenly when coming on the stage or interrogating on court, which is particularly dignified and solemn since it is a rattle different from other types of operas.

In string music, Qi Hu, Yue Qin, sanxian, and Banhu is called the four major pieces. Qi hu, the main musical instrument, needs special processing. The tube is made of bamboo, with small and long tube body. The tube mouth is trumpet-shaped, the qin column is equipped with iron bar, and the bow is equipped with steel wire, so that the timbre is high, crisp and loud.

In the wind music, the suona accompaniment of Qi Opera occupies a large proportion, which is an important part of the whole accompaniment music. Suona is a colorful instrument, which can render the atmosphere and add to the plot in the performance and often show a special effect. The qupai of Suona is rich. There are about 300 spread in Ninghua. It can roughly be divided into four types according to the needs of different plot: solemn atmosphere of officialdom type, majestic atmosphere of military officers and war type, bright and happy atmosphere of wedding type, and low and sad atmosphere of death funeral type.

The music of Qi Opera is also refreshing, which can be divided into big and small brands according to the plot. Big brand uses a pair of suona to choose to play the above four types of music according to the need. Small brand uses flute, $\mathrm{Hu}$ Qin, sanxian and other instruments to play a light and smooth tune, which are more used to express the thoughts and feelings of the characters.

The band of Ninghua Qi Opera was relatively complete and regular in the early days. Generally, it is composed of 9 people, including one for main instrument and Suona, 2 people for Erhu, one for Dihu, one for Yangqin, one for Shuang Qing, one for Guban, one for big gong and Cymbal, and one for small gong. Later, due to the lack of funds and staff, the band was gradually tightened. After 1958, civil and military occasions only had 5 people, namely the one for main instrument and one for Suona, one for Erhu, one for big gong and cymbal, one for small gong, and one for Guban, which is simplified.

3) Bright outfits and simple make-up: The costume and make-up of Qi Opera have three remarkable characteristics: First, drawing face and cloth system hair all use three basic hues: red, black, and white. There is the saying of red loyalty, black straight, and pink (white) evil, roughly including the main types of characters. The second is drawing a rosy red "dot" between eyebrows of small sheng, which can make him look particularly handsome. Third, python and armour is made by Guangxiu, with innumerable mercury small round lens embedded, sparkling and dazzling in the light.

Facial makeup pays attention to the outline of the eye, nose, and mouth, and the line is smooth and powerful. Hua role and chou have general face and special face, which is selected to use according to the type of loyalty, evil, good and evil. The pink face of hua role is a kind of common face, which is mostly used for fatuous ruler and traitor minister, such as King Zhou of Shang, Cao Cao, Dong Zhuo, and Yan Song and so on. The special face is to show the personal character. For example, Guan $\mathrm{Yu}$ is particularly loyal to friends, so he is painted red face; Zhou Cang can swin well, so he is painted with a shrimp; Li Kui is clawed when hitting the tiger, so he is painted with a tiger claw; Meng Liang is good at using fire to attack, so he is painted with the fire gourd. These forehead marks make special facial makeup intuitive and concise. For chou, only Cheng Yaojin, Sun Wukong and Liaokong monk have the special face, and others all fall into the four types of faces including treacherous face, bad face, thief face, and baby face. Small dan needs to powder and paint red, draw eyes and fill the eyebrow, which is more exquisite. Other roles do not need to powder; the old sheng only adds the bun while sheng roles only add the beard and crown belt, which is simple.

In order to facilitate the performance of "wrist skill", Qi Opera use Luokou sleeve. The flag is tied on the waist, so the left and right spread range is small. Dan roles use seven star foreheads, with seven pearls prefixed ahead, and color velvet balls in it, with right and left coronal ear protection, looking elegant. As for boots, hua lian uses high wooden boots, while sheng and chou use fast boots with flat-bottomed.

\section{INHERITANCE AND PROTECTION OF NINGHUA QI OPERA}

\section{A. The Inheriting Value of Ninghua Qi Opera}

In the summer of 1981, experts from Hunan Opera Research Institute and the repertoire room of Qiyang area came to Ninghua to investigate the activities of Qi Opera and were touched deeply. They said that in Hunan, Qi Opera have already been improved and changed, while the performance patterns of singing, reciting, acting, and playing of Ninghua Qi Opera retains the ancient style and charm of Qi Opera, which is the "living fossil" of the ancient Qi Opera in Hunan. "Fossil" is a kind of rock which is changed from the remnant of ancient living things buried underground. It is a specimen to understand the evolution of ancient living things, which is of great research value. Opera experts refer to Ninghua Qi Opera as "living fossil" of Hunan ancient Qi Opera, showing the special position of Ninghua Qi Opera in the evolution history of Qi Opera, which is precious.

As a large-scale local opera, Hunan Qi Opera inherits from Jiangxi Yiyang opera, retains its own characteristics, and spreads to west Fujian and Guangdong Han opera. It spans five or six centuries, and is widely distributed in many areas of Jiangnan, especially in Hakka areas. Its unique artistic charm infects the broad audience of generation after 
generation, and the popularity is high in Ninghua. The reason why Ninghua Qi Opera can keep the original taste of ancient Qi Opera is that there is neither new kind of drama derived from it nor the traces of later transformation. This reason should be varied. First of all, the Ninghua Hakkas have a rigorous spirit and a serious attitude towards all foreign customs, beliefs, and other cultural matters. As long as they are willing to accept it, they will carry it on, and they will warn each other: "Don't let it lose in our hands!" This respect for the original appearance is in line with the current concept of "intellectual property rights", without the backward factors of superstition and self-preservation. Secondly, the stage art in the history of Ninghua is blank, so there is no problem of fusion or combination. After the introduction of Qi Opera, due to the restrict and influence of many conditions such as remote mountainous area, backward economy, and low education, the requirements of the common people for cultural life are not high, and they never get bored watching familiar traditional operas, resulting in the standing still of Qi Opera. Third, the activity groups of Ninghua Qi Opera are the folk amateur organizations that perform the ancient costume play. This positioning is like a protective membrane, so that it can avoid the impact of the political culture wave in the name of "reform and innovation". Propaganda work adopts the fashionable modern song and dance, and never needs Qi Opera; literary criticism has professional troupes of other types of operas, and never needs it. Therefore, it is put aside and no one would listen, like the "fossil" sleeping in the ten years of chaos without being hurt.

\section{B. The Existing Situation of Ninghua Qi Opera}

The spring breeze of reform and opening-up has blown the land of China and awakened the Chinese opera art which has been sleeping for many years. In the village of Hakka in Ninghua, Qi Opera comes to life. In the 80s and 90s of last century, the county cultural department held a Qi Opera show in Cuicheng, and the Qi Opera Troupe of Helong won the champion prize in the competition. However, with the rapid development of the times, high-tech has stepped into the $21 \mathrm{st}$ century, with television, audio and other entertainment media coming into the countryside and the family. Rural cultural life is also increasingly rich, so people's enthusiasm for Qi Opera can no longer compare with the past. The audience is decreasing and the management situation is getting worse. Up to 2008, the troupes that still perform for others in Ninghua are only three troupes: Helong Xiayi, Anyuan Wufang, and Shashimen Mountain. On 2010 Spring Festival, Anyuan and Zhongsha troupe didn't accept any play, so only Helongxiayi was still working hard to support. The problems they faced with are the same as other troupes.

The first is the loss of a large number of viewers, which is not only a universal problem, but also the inevitable result of the development of the times. Because the audience in the past was in agricultural society, there was no livelihood to keep busy with during the fallow years, and there was no other entertainment, acting was often for the sake of festive celebrations. The main purpose of watching a play was to watch the act and listen to the characters, without paying attention to the plot of the story, and do not care about the repetition of the old play. As long as singing skills meet the appetite, the audience will enjoy watching. The mainstream of the audience today is the young generations who are in the information society and busy with new things every day. The pace of life is changing quickly, so they want to seek the fresh stimulation that is close to life even if they want to relax and entertain rather than spend the time and energy on always "repeating the story of yesterday" (popular lyrics). Naturally they won't have much interest in the traditional opera about emperors and generals.

Second, the theater troupes are amateur organizations that master limited repertoire originally and their basic skills are also limited. At present, most of the actors are working outside separately, so it is very difficult to have the chance to rehearse centrally and improve their acting skills. The repertoire can't be updated, so they always perform the old ones. Today, with the diversity of entertainment, if there is no strength of competition, it will lose living space.

Third, the audience is few, the number of performances declines, and income decreases, so they can't afford to buy expensive clothing and props and the actor's income cannot support the family. The present actors are aging and young people who are willing to study opera become less and less, so the inheritance of Qi Opera is facing the dilemma of lacking successors.

\section{CONCLUSION}

At present, the whole country attaches great importance to the protection of intangible cultural heritage, and the protection of intangible cultural heritage has become a major strategy for the development of national culture. Qi Opera is an excellent cultural heritage as well as precious cultural resources of Ninghua, so the publicity and culture departments of Ninghua County are taking various effective measures to protect. On the one hand, a "non-material cultural heritage protection agency" is set up to draw up a long-term protection plan, build database and showroom, and compile a series of conservation books. On the other hand, we should begin to set up the county Qi Opera Troupe as soon as possible to raise funds, allocate staff, intensify training, and improve the level. We should especially make efforts in performing repertoire, advocate modern themes that are close to the lives of the people, inject socialist moral thoughts of "Eight Honors and Eight Disgraces" and bring good people and good deeds to the stage to create fine artistic works that young audiences like through opera means, enhance the competitiveness of Qi Opera and make Qilian opera, the flower of ancient folk art, replay in the red land of Ninghua Hakka and be inherited from generation to generation to add strength to the prosperity of Ninghua opera art.

\section{REFERENCES}

[1] Li Jingzeng, Huang Zongxian, Fujian Provincial Local Records Compilation Committee. Records of Ninghua County, Xiamen 
University Press, 2009. 黎景曾、黄宗宪修纂, 福建省地方志编纂 委员会整理《宁化县志》, 厦门大学出版社, 2009 年。

[2] Li Shixiong, Committee of Ninghua County Records Compilation, Fujian Provincial Local Records Compilation Committee, Records of Ninghua County, Fujian People's Publishing House, 2012. 李世熊修 纂, 宁化县志编纂委员会整理, 福建省地方志编纂委员会主编 《宁化县志》, 福建人民出版社, 2012 年。

[3] Lian Yundong, Qi Opera in Ninghua, Fujian Hometown, No. 05, 2006. 连允东《祁剧在宁化》, 《福建乡土》2006 年第 05 期。

[4] Lin He, History of Chinese WuNuo: A Preliminary Study on the Gene of Chinese Civilization, Guangdong flower town Publishing House, 2001. 林河《中国巫傩史: 中华文明基因初探》，广州花 城出版社, 2001 年。

[5] Tan Yuanheng, Huang He, Introduction to the Aesthetics of Hakka Culture, South China University of Technology Press, 2001. 谭元 亨、黄鹤《客家文化审美导论》, 华南理工大学出版社, 2001 年。

[6] Wang Jianhe, Zhang Biaofa, Hakka Folk Music in Ninghua, the China Overseas Publishing House, 2000. 王建和、张标发《宁化客 家民间音乐》，中国华侨出版社，2000年。

[7] Wang Yaohua, Hakka Art Culture, Fujian Education Press, 1995. 王 耀华《客家艺能文化》, 福建教育出版社, 1995 年。

[8] Editorial Committee of Chinese Traditional Opera Records, Fujian Volume of Chinese Traditional Opera Records, Culture and Arts Publishing House, 1993. 中国戏曲志编辑委员会《中国戏曲志 - 福 建卷》, 文化艺术出版社, 1993 年。 